\title{
9. Becoming Privileged in Australia: Romany Europe, Indigenous Australia and the Transformation of Race
}

\author{
Oliver Haag
}

This chapter explores the different discourses of race as they affected my position as a German-speaking scholar of Indigenous Australian studies. There are difficulties, at times even impossibilities, in translating Australian meanings of race into a German-speaking context. The silencing of 'race' in German-speaking academia, especially in leftist circles, has led to a difficulty to reclaim difference. This silencing was cracked in Australia, where I had suddenly 'inherited' more than one race. The retranslation of these discourses into German-speaking contexts meant, again, a loss of my race and proved a difficulty for German-speaking scholars to handle a concept so profound for (Indigenous) Australian studies: race.

'What is the gain for scholarship if the world knows that you like pasta, stay up late and have a love for French movies?', commented an Austrian historian sarcastically on my efforts to engage in ego-histoire. I answered that I was not planning to write merely about myself but also about Australia and Europe. I was intrigued by the different discourses of race, I said, and reflecting on my own 'race', or what in German would be called ethnischer Hintergrund ('ethnic background'), would illuminate some of the mechanisms and assumptions of writing about race in different cultural contexts. 'This is pretty essentialist', he said. 'So I shouldn't have a race?', I replied. 'You are white anyway.'

This answer is informed by the privilege of deracialising not only white people but also white researchers. The idea of researchers being free of any race due to their perceived whiteness is, in this event, backed by the moralising argument of not engaging in seemingly essentialist rhetoric, hence not to speak of racial positioning. 'Let's just leave this and return to serious research', was the reply I received. Such hidden privileges in academic research have undergone critical assessment in the humanities and social sciences which has entailed, at least on a theoretical level, an increasing dissolution of the hierarchical relationship between informant and interpreter, object and subject (for example, Devereux 1967; Erdheim 1982, pp. 9-40). Along with this dissolution, the postulates of objectivity in the production of knowledge have been dismantled as an epistemological impossibility (von Glasersfeld 1995), and a tendency has evolved to highlight the ethical implications for academic research (for example, 
Hesse-Biber \& Leavy 2006, pp. 59-92; Christians 2005). Critical whiteness and Indigenous studies in particular have deflected attention towards highlighting racial privilege in the production of knowledge (for example, Smith 1999; Janke 1997; Denzin et al. 2008; Riggs 2006, pp. 91-113).

When Pierre Nora edited the collection Essais d'Ego-Histoire in 1987, the scrutiny of researchers was in its infancy, especially so in German-speaking academia. The term 'I' had to be strictly avoided in scholarly texts; as an undergraduate student in Vienna I was still taught that passive constructions and the plural 'we' had to be employed. Essais d'Ego-Histoire is deeply ethnocentric and 'colour-blind': all contributors to the volume are white, there is only one female contributor, and race is not made an issue. In Europe, despite a translation into German, Essais d'ego-histoire has not been as widely received as Nora's other works, especially Les Lieux dé Mémoire. Nora speculates that this is perhaps because the time was not ready for the book (Nora 1984) because western academics still grapple with how to integrate personal stories into a generalised and abstract narrative. Perhaps this is also because personal narratives, other than those of the 'other', the 'Indigenous', for example, sound too trivial for academic purposes? The interest in self-reflection seems to be much stronger with Australian than European historians. As Jeremy Popkin observes, Australian historians have published more works in the genre of ego-histoire than any other historians, including the French (Popkin 2007).

Despite its ethnocentric origin, ego-histoire is nonetheless a useful tool, especially so for a biographically-orientated study of researchers. This question is all the more important in relation to the European contributions to Indigenous studies, which are evident yet remain largely unexplored (Peters-Little, Curthoys \& Docker 2010). There are, for one, more books on Indigenous Australian life histories that have originated from Europe than from Australia. Europeans, I had been told in Australia, have it easier in collaborating with Indigenous people. A recent biographical study by Fiona Paisley has uncovered that some Indigenous political activists not only put more hope into Europe than into Britain but also evinced more admiration for Europe (Paisley 2012). European-Indigenous relations seem to be of different character than Anglo-Saxon-Indigenous relations. I can only speak for myself, without making any generalisations about other European scholars: what was my incentive to undertake research in Indigenous studies and how do I relate my 'self' to my research? Ego-histoire fills an important gap in the understanding of the practices of Indigenous studies from the distance of Europe.

Ego-histoire, however, needs to be removed from its original context in order to make sense for a transnational approach to Indigenous studies. The first step to such an approach is to explain what ego-histoire is not. It is commonly understood as an autobiography written by an academically trained 
historian (Popkin 1996; Schulze 1996, p. 13). This specialist authorship makes ego-histoire, by definition, different from conventional autobiographies: egohistoire does not ponder the entire spectrum of a life but focuses on professional life. Henry Reynolds' Why Weren't We Told (Reynolds 1999) and Ann Curthoys' Freedom Ride (Curthoys 2002) — the latter being possibly less autobiographical but nonetheless relying on personal remembrances - count among the most distinguished contributions to what can be termed ego-histoire in Indigenous Australian studies. Such ego-histoires are written by established scholars who can reflect on the full scale of their academic careers. In this, I argue, these autobiographical works constitute a distinct genre of history. This chapter is far from being such an 'autobiographical history'.

As an emerging scholar, unable to reflect on an entire academic life but rather on a comparatively short period of professional work, I regard my project of ego-histoire as a method rather than a genre of history - even if Pierre Nora stresses the importance of not conceiving of ego-histoire as a method. Still, as German historian Lutz Niethammer suggests, ego-histoire can be seen as a tool of deconstructing the social categories which affect scholars and influence researchers in their work (Niethammer 2002). The project of telling my ego-histoire is thus not concerned with exposing my life in the way a conventional European autobiography would do, but is rather about assessing those social categories that affect my research and ask how they have been reshaping my work. Hence I consider it important to differentiate between autobiography and ego-histoire, on one hand, and ego-histoire as a genre and ego-histoire as a method, on the other.

Gillian Cowlishaw addresses Aileen Moreton-Robinson's demand for white researchers to reflect on their racial privileges thusly: 'How can we respond? How can those privileged by racial power divest themselves of privilege and engage in a decolonising enterprise?' (Cowlishaw 2004, p. 66). Ego-histoire is one possibility, I think, to divest of privilege. Although certainly selective, ego-histoire has the potential to uncover the hidden privileges of researchers by exposing personal motivations, family histories, political and academic ambitions, all of which can be potentially hurtful processes.

\section{From Austria to Australia}

My academic journey to Australia started on a rainy day in Vienna in the northern summer of 2003. I had completed a seminar on 'Autobiography, Gender and History', and came across an article that mentioned the phenomenon of Australian history being rewritten by Indigenous autobiographies. I cannot remember the details of the article - it might have been one of Sidonie Smith's 
works - but I clearly remember that I started a search of the library catalogue for Indigenous autobiographies, which eventually returned a few titles, including Don't Take Your Love to Town and Auntie Rita. The first Indigenous book I read was Rita Huggins' biography Auntie Rita (Huggins 1994), followed by Ruby Langford Ginibi's Don't Take Your Love to Town (Ginibi 1988). I had very thin knowledge of Australian history and did not know the names of Indigenous intellectuals, writers and artists. Despite my lack of knowledge, I was immensely impressed by Auntie Rita. The rewriting of history and the courage of talkingup to academic historians, without moralising and victimising, impressed me the most. My reading experience of Don't Take Your Love to Town was similar. I was impressed by Ginibi's fiery and clear style. I liked the sense of resilience and the agency in both authors.

Despite the otherwise unfamiliar contexts of Indigenous autobiographies, their rewriting of history offered a familiar reference for personal connection. As I have argued elsewhere, German audiences tend to read Indigenous films and literature according to culturally familiar and recognisable codes of reference (Haag 2010, 2012). Rabbit Proof-Fence, for example, has been interpreted in Germany through the lens of the Holocaust. I too initially related my perception of Indigenous cultures to codes familiar to my own cultural contexts. Having grown up as the grandchild of a Romany grandmother, the first time I was confronted with Romany people in Austrian history was at university. A lecturer mentioned that Romany people - he derogatively called them 'gypsies' - had been his most 'difficult' interview partners because, as he said, they lied all the time. More well-intentioned academics talked about the fate of the 'gypsies' as the most disadvantaged group in Europe. Romany people were subject to racial persecution throughout the past and even today they count among the most discriminated groups in the European Union (see, for example, Rose 2007; Zimmermann 1989). Romany people lead the statistics as the least educated and poorest Europeans, with the lowest life expectancy and highest unemployment rates. Romany history, it seemed, was one of destitution and misery. It was only after reading Auntie Rita and Don't Take Your Love to Town that I became angry with what I started to perceive as the misrepresentation of Romany people and a glaring absence of scholarly self-reflection. 'Romany people are not merely problems and poor victims', I told my mother, who replied in her sarcastic way, 'Relax, boy, we are immensely rich in being misrepresented'.

My mother was the first in her family to be born in Austria. My father is originally from Slovenia. My mother's parents came from Romania. Her father belonged to the German minority of the Banat, a region inhabited mainly by Romanian and Hungarian nationals but also settled by Germans during the seventeenth and nineteenth centuries. Part of the Austro-Hungarian Empire, the Banat region comprised several ethnic minorities, including Romany people. 
My grandmother was Romany, but had concealed her racial heritage for almost her entire life. 'Who wants to be someone like that?', she commented on my mother's desire to unearth her roots. My grandmother left Romania before the coming of communist rule. Barred from her relatives, she left her native country for good and never reconnected with her people (partly because this was almost impossible in light of travel restrictions, but she also rejected any contact with her kin).

There were also national divisions in my family line: my maternal grandfather, though part of the German minority in Romania, chose to stay in Austria and started to hate Germans. What a contradiction, I thought. But he was adamant and declared my uncle a persona non grata for marrying a German woman. My mother was made unwelcome by my Yugoslav grandfather who, as a former resistance fighter against the Nazis, considered all Austrian women fascist sluts. Ironically, he was one of the few people to consider my mother Austrian; her darker skin colour (much darker than mine) made Austrians tend to classify her as a foreigner and occasionally as a 'gypsy'. I have grown up with national categories which were ubiquitous in spreading agony across my family. Only my Romany heritage could bridge the family divisions: everyone agreed that Romany people were lazy Sozialschmarotzer (social parasites).

A German studies scholar once asked me whether my interest in Indigenous Australia reflected my effort of forging a Romany identity. 'How could I?', was my reply. 'I don't identify as Romany.' I did not grow-up in Romany culture. For most of my life I was not even aware of this heritage (on the demand of my grandmother, my mother silenced our racial origin until a few years before my grandmother's death). After having read Auntie Rita, I contacted Jackie Huggins and told her how much I enjoyed her book. Her welcoming hospitality and my many positive experiences with Indigenous writers encouraged me to remain in the field of Indigenous studies (I hasten to add that I also write about Australian topics generally, as well as Romany studies). Out of my initial fascination with the rewriting of history, I have started to explore new fields, including Indigenous book production and the European interest in Indigenous cultures.

My Romany heritage had never dominated my interest in Indigenous Australia. Rather, Indigenous intellectuals have influenced some of my views on racial representations in Europe. I recently joined an activist event in Berlin directed against antiziganism (a term coined to refer to the patterns of prejudice against Romany and Sinti people). The activists in the forum (all non-Romany) remarked that Romany people were a construction of antiziganist discourse, and hence passive victims of racism. Although the audience was well-intentioned, I could not suppress uttering critical remarks which had been inspired from what I have heard in Australia: 
I am an Aboriginal woman who was raised by two Aboriginal parents, who was just too determined and proud of being Aboriginal and lucky and I don't wear my oppression. You know. Other people may dispose me and deny me opportunity but, you know, come on, the reality of it is that we are sitting in my office right now and I have my salary, you know, I am a deputy director of a centre in a university, I am doing my PhD, I've travelled around the world, I've written, I've made several films, I'll be writing in several books in the future, I've had several careers as a film maker, historian and a writer and a singer-musician and so if that means being oppressed, then fine (personal communication with F Peters-Little, Canberra, 13 August, 2004).

Drawing on this critique of oppression, I asked the participants whether they detected any construction of victimhood in their political agenda which might unconsciously replicate antiziganism in their antiziganist critique. While my critique largely fell on deaf ears, with only partial acknowledgment, the salient point is that my question has been profoundly influenced by an Indigenous Australian intellectual whose critique offered an utterly transnational dimension to connect to racial representations in Europe. Whether this influence is regarded as an impetus for forging my own identity as a person of Romany descent is of secondary importance. (I think we all reshape our personality with recourse to biographical experiences). Of primary importance is the circumstance of Indigenous Australia having become part of my intellectual and political stance in Europe. As a famous quote in Ulysses reads, 'I am a part of all that I have met'. Although written in different context, I have become, in a sense, a part of all that I have met. The Australia that I have met transformed into a biographical journey, a journey as much academic as it is personal.

\section{Gaining a Race}

In 2004, as part of my research on published Indigenous Australian autobiographies, I conducted 22 interviews with Indigenous and nonIndigenous Australians. This was the first of my journeys to Australia in which 'race' became a vital part. In this chapter, I will therefore dwell on the unfolding of 'race' during this transnational journey. The informal talks and interviews related to my position as a researcher in which I had been confronted with my race. I had been aware of ethical protocols and speaking positions in Indigenous studies, mainly through Jackie Huggins's Sister Girl (Huggins 1998) and later through the writings of Terri Janke. But I had not been prepared with how to deal with my own 'race'. Indigenous respondents seemed to have questioned my race differently from non-Indigenous respondents: the former asking about my biographical background, while the latter usually took my belonging to the 
white race for granted. Although I have frequently travelled to Australia since 2004, these interviews were the most intense situation in which my 'race' had been discussed.

The interviews with emerging non-Indigenous scholars proved to be the most complex. In more than half of all cases I could feel distrust. One respondent even refused to have her interview recorded because, as she said, she loathed being 'misrepresented'. Two non-Indigenous interviewees reminded me how to behave correctly when interviewing Indigenous persons, advising me that Indigenous people were much stricter concerning consent papers, and that I would need to clearly indicate my intentions and background. None of the nonIndigenous respondents inquired about my background; their witnessing of me coming from Europe seemed to be enough of a biographical background. One respondent, after having explained what she termed the 'difficulties' in interviewing Indigenous persons, eventually tried to put my mind at ease with a reassuring 'but don't be afraid of them'.

This anxiety and distrust reflects the debates about the legitimacy of nonIndigenous research as well as debates about the ethics of cross-cultural research in Australia (Bell 2004, pp. 26-27; Huggins 1998, pp. 83-84). It also mirrors the reversed constellation between interviewee and interviewer: one respondent who had regularly interviewed Indigenous persons confessed to me that the situation of being interviewed made her feel extremely unconfident - it was the first time that the researcher had become the researched. I regularly encountered anxiety and self-doubt among emerging non-Indigenous researchers:

I would never say I write Aboriginal history for myself because I am not Indigenous, but I stay in a field because at present there is pressing research that needs to be done particularly on oral histories that you need to catch people before the generation has died and there is just not enough Indigenous researchers to replace me. I'd love to replace myself and do something else because I know there is this material I just can't access. Because there is no good reason an Indigenous person should trust me. I am just another whitefella. I might be well intentioned but good intentions have done some terrible things in the past (personal communication with J Jones, Melbourne, 4 August 2004).

I was impressed by the power that Indigenous intellectuals have gained over academic research in Australia (despite this power being limited). Such a situation was utterly unfamiliar to the Austrian context, where Romany studies are almost completely in the hands of non-Romany people (or, in the Romany language, gadje people). I liked the expression made by the respondent and imagined what a relief it would be to hear a similar response in Austria of a gadje person considering her- or himself just another gadje. This decentres white 
hegemony. The 'just another whitefalla' category also, as far as non-Indigenous scholars were concerned, included me. I was not sure how to handle this newly inherited category, being considered implicitly a member of the white race. In Austria, because of my physical size and darker skin colour, I have often been considered a 'migrant', and in the region where I grew up - the southern Burgenland, which has a large Romany population-a 'gypsy'. I was never classified as a member of the majority population in Austria.

Race has an entirely biologistic meaning in Germany, mainly because human groups had been racialised and persecuted on grounds of their construed race (Fehrenbach 2005, pp. 6-7). As Gillian Cowlishaw argues, the concept of race was also rendered silent in Australia and has often been substituted for 'culture' (Cowlishaw 2004, pp. 59-60). In Germany, however, the concept of race has never regained acceptable status among scholars, even though Austria and Germany continue to be fundamentally racialised. For example, citizenship laws in both countries still premise primarily on the jus sanguinis, an utterly blood-based concept of citizenship transferred by the birth of a citizen parent (Yuval-Davis 2011, pp. 68, 72-73). Paradoxically, although the German-speaking world remains extremely racialised, the language of race has been erased. Rasse, the German equivalent of 'race', denotes something similarly degrading to 'breed' and 'species' in English (Brewster 2009), without any complexity that would allow a social understanding of race. The category of 'white' races has a similarly problematic connotation and been largely excised from political parlance, although both countries are deeply engrained in whiteness.

In Austria, I have usually been excluded from Austrianness on the grounds of my physical appearance, which does not seem Austrian enough. In Australia, by way of contrast, I was implicitly included as a fellow member of the white race. Non-Indigenous interviewees implicitly considered me to be 'one of them'. While nobody explicitly said 'be aware of them because you are white', my perceived whiteness was nonetheless inherent in their reactions. This remark is not meant as a moralising critique, as I do not consider the racialisation of my person as necessarily evil. I harbour many positive memories of non-Indigenous Australian colleagues and friends.

My race was questioned differently by Indigenous interviewees, mainly they asked me biographical questions. Surprisingly, after having heard all the warnings, my interviews with Indigenous respondents proved to be the easiest to conduct. I encountered interest and immense support, which I had not expected. I received a very interesting comment: 'Why can't Australia be like Germany?' It was a time when the official apology for the Stolen Generations still seemed far away. My national background - with which I do not identify - has been regarded as something positive by many of the Indigenous Australians I interviewed and have since worked with. But I remember another, more critical 
comment: 'Racism in Germany is quite bad.' 'Hallelujah, the first Aussie who is critical of Germany!', I replied, and we started to make fun of Germans. This broke the ice.

To the Indigenous Australians I interviewed, my racial heritage has proven to be of greater relevance than the national one. Many Indigenous respondents became interested in my Romany heritage. In Austria, I had entirely negative experiences with my Romany descent. No one wishes to be a 'gypsy' in Austria. In Indigenous Australia, it made connections easier and became a bridge between the different narratives of race in Europe and Australia. During discussions with Indigenous intellectuals, my 'race' had become increasingly transformed. Indigenous Australians treated my Romany heritage on first view as a racial category, just as white Australians treated my whiteness as a racial category. All of them were at ease in referring to me (and themselves) racially, but this racialisation was neither fixed nor essentialist, it was restricted to biographical and less racially determined questions. The question about my biography suggested flexibility for my racial identity. For the first time in my life, my Romany heritage was not related to my physical appearance. It was rather my biography-in-the-making that informed cross-cultural encounters. Journeying to (Indigenous) Australia has become a part of me, a part of all that I have met.

An Indigenous woman with Austrian ancestry asked whether Romany people were black, that is, whether they designated themselves as 'black'. 'My grandmother didn't really look very black', was my naive reply. 'Blackness isn't about the colour of the skin', answered my Indigenous host, uncovering my unconscious replication of Austrian racial narratives as deeply steeped in physiognomy. Romany scholar Ian Hancock argues that, linguistically, the selfdesignation in Romany language, kalé, denotes blackness, while gadje refers to Caucasian non-Romanies (Hancock 2008, p. 186). But neither in Austria nor in Romania would most Romany people self-identify with a global blackness. The remark of blackness was not merely abstract in relating to a racial group, but also applied to my grandmother (and indirectly to me). My answer was 'no', my grandmother was not black. But did this make her (or me) white? I am in-between Romany and white. I suddenly realised that I had no words to designate my race: a typical sign for privilege.

I have never self-identified as Romany because I do not have any connection to Romany people in Romania. There is also a veritable difference between being Romany and being of Romany descent. My journey to Australia uncovered some of the transnational narratives of race that impacted so differently between Austria and Australia. Having 'inherited' a race in Indigenous Australia meant an escape from an immensely racialising world in Austria that has stripped itself of the language of race. The 'inheritance' of race, however, was not of an essentialist nature but showed a profound flexibility in conceptions of race as 
a biographical journey and conferred a positive perception of Romany people. It was in Indigenous Australia that I saw, for the first time in my life, Romany people being perceived just as humans, not as problems or as exponents of a romanticised world. Moreover, apart from the question of whether Romany people self-identified as black, my whiteness was treated with surprising flexibility, which could indicate an inclusion of my Romany descent in my whiteness without reducing my biography to merely one racial category. There is a profound critique of Indigenous essentialism which Vicki Grieves has recently rebutted as an extension of Indigenous kin and country (Grieves 2008, p. 301). My biographical journey, although resting on individual experiences that might not be readily generalised, shows a view of Indigenous narratives of race as containing highly different connotations from western essentialism. Categories were important to make connections, but they were neither dominating nor excluding.

\section{Losing a Race}

In many of my encounters with Indigenous and non-Indigenous Australians my perceived race proved to be a dominant category determining our mutual relationship. This conception of race was not necessarily biologistic. In Europe, I would not simply use the concept of Rasse. Some things remain impossible to translate. But meanings of race as a social category are not completely untranslatable. Subjected to forcible assimilation, Indigenous people in Australia had often been denied the right to be different. In German history, (racial) difference had not been suppressed but established. In Australia, Indigenous claims to difference are part of Indigenous sovereignty and reflect the history of forcible assimilation, dispossession and colonialism. Such claims are difficult, yet not impossible to translate into a German-speaking context. Without translating the cultural contexts, Indigenous sovereignty is likely to be misconceived as a form of essentialism. Ego-histoire shows the importance of such a translation to render visible the common misunderstanding between different cultural contexts (Haag 2010, 2012).

Upon my return to Austria, I presented some of my findings to my academic peers. I reported on the protocols of ethical conduct and the issues of sovereignty. I argued that Indigenous autobiographies were also histories. It was recommended that I write my thesis in German to avoid what was called the political demands of ethical conduct. I was told that autobiographies could never be considered history; historians were professional writers (supposedly not Indigenous people following sovereign intellectual traditions). Based on the Indigenous critiques I encountered in Australia, I argued for the need to deracialise German history, feminism and autobiography. 'It's a question of 
race', I said. (I did not use the term 'whiteness', due to the lack of a German equivalent). I was told that it wasn't. 'Race doesn't exist, so drop this dangerous argument.' 'There's nothing to be deracialised.' 'If the Australians are obsessed with race, that's their problem. You shouldn't be.'

I was home and had lost my race again. Last year, I submitted a semiautobiographical article on Romany history in which I criticised some of the scholarship that construed Romany people as deplorable victims of the past. I did not like the moralising and patronising rhetoric employed in this scholarship. Reading referee reports on the article, I recognised how much I had become influenced by Australian debates of racial representation and essentialism (for example, Anderson 1995, p. 37; Moreton-Robinson 2003, p. 32; Birch 1993, p. 21; Lattas 1993, pp. 244-246). Referees had criticised my employment of the terms 'cross-cultural' and 'inter-cultural' to designate the differences between Romany and non-Romany people. This, it was argued, was essentialist rhetoric. 'Cross-cultural' implied the idea of two opposite cultures, which was regarded as essentialist. It is impossible to write about racial prejudice and privilege without using the terms that illuminate the patterns of racial normalisation (Haggis 2004, pp. 51-52). A mere moralising of essentialism (actually imposed by white people) is analytically unconvincing and oversimplifies the complexity of politics of race.

Non-Indigenous people frequently ask me why I had not had made negative experiences in Australia-I had received constructive critique but never been urged to leave the field. Some think that my perspective as an outsider, especially so as a European, has been helpful. But aren't Europeans part of the problem? Aileen Moreton-Robinson, Maryrose Casey and Fiona Nicoll argue for a transnational theorisation of whiteness, implying that Europe is still part of the domination of Indigenous people around the world (Moreton-Robinson, Casey \& Nicoll 2008). My Europeanness thus offers a burdened rather than liberating position. I was asked if my Romany heritage had been central. I do not think so. Despite a few similarities, Romany and Indigenous cultures are far too different to be compared. My age and gender are also deemed influential. 'It's rather rare that white European boys are fascinated by the power of black Australian women's writing', was one of the comments a feminist friend made. True, the first texts I read were authored by women, but my fascination did not derive from the authors' gender but from their self-determination. In the end, I think the positive experiences were mostly coincidental, and disappointing experiences may come.

During the journey to my ego-histoire I have discovered that speaking about race can be relieving. I have discovered how much Australia has become an intellectual home. Not that I always agree. I have gained the impression that white people are sometimes homogenised in interracial debates in Australia, 
just as Indigenous people often are. The idea of forgetting about one's race is principally an act of privilege. Yet this is not always the case, especially where white people have hybrid heritage. As Nell Irvin Painter has pointed out, the history of white races is complex and is not distinguished by privilege in all contexts (Painter 2010). In Europe, it is not a racial privilege to be part-Romany. Yet in Australia it is. My perceived whiteness, the fact that I can pass easily, is a privilege. I am part of white academic practice and power relations. Whiteness, if taken out of its local and national contexts, transforms privilege.

The practice of ego-histoire is one of recognising the complex interplay between whiteness, nationality, age, gender and personality in the mutual relationships between Indigenous and non-Indigenous people. There are no simple categories at work that decide on one's personal experiences in crosscollaborations and engagement. As diverse as Indigenous and white people are, so are the relationships between Europeans and Indigenous Australians. It was neither my race nor my national origin that were truly decisive of my position in Australia. The reactions shown by the Indigenous respondents proved that all these categories were of importance merely during the first encounter in establishing a common relationship. Soon, however, these categories slipped into relative unimportance. Apart from encounters with my Romany friends, I have never felt so comfortable with my Romany heritage than among Indigenous Australians, not because my Romany heritage had been racialised as determined, but rather because it had become seen as undetermined through journeying between different worlds. Undetermined in its openness and non-physiology, race appeared highly different between its occasionally harsh rhetoric and its lived practice. Race matters. But it does not always matter.

\section{References}

Anderson, I 1995, 'Reclaiming Tru-ger-nan-ner: De-colonising the symbol', in $\mathrm{P}$ van Toorn \& D English (eds), Speaking Positions: Aboriginality, gender and ethnicity in Australian cultural studies, Department of Humanities, Victoria University of Technology, Melbourne, pp. 31-42.

Bell, R 2004, 'Aboriginal Art: It's a white thing', in M West (ed.), Telstra National Aboriginal \& Torres Strait Islander Art Award: Celebrating 20 years, Museum and Art Gallery of the Northern Territory, Darwin, pp. 20-29.

Birch, T 1993, "'Real Aborigines": Colonial attempts to re-imagine and re-create the identities of Aboriginal people', Ulitarra, vol. 4, pp. 13-21. 
Brewster, A 2009, 'Teaching the Tracker in Germany: A journal of whiteness', in B Baird and D Riggs (eds), The Racial Politics of Bodies, Nations and Knowledges, Cambridge Scholars Publishing, Newcastle upon Tyne.

Christians, C 2005, 'Ethics and Politics in Qualitative Research', in N Denzin \& Y Lincoln (eds), The SAGE Handbook of Qualitative Research, third edition, Sage, Thousand Oaks, pp. 139-164.

Cowlishaw, G 2004, Blackfellas, Whitefellas and the Hidden Injuries of Race, Blackwell, Oxford.

Curthoys, A 2002, Freedom Ride: A freedom rider remembers, Allen \& Unwin, Crows Nest.

Denzin, N, et al. (eds) 2008, Handbook of Critical and Indigenous Methodologies, Sage, Thousand Oaks.

Devereux, G 1967, From Anxiety to Method in the Behavioral Sciences, Mouton, Paris.

Erdheim, M 1982, Die Gesellschaftliche Produktion von Unbewußtheit: Eine Einführung in den ethnopsychoanalytischen Prozeß, Suhrkamp, Frankfurt/ Main.

Fehrenbach, H 2005, Race After Hitler: Black occupation children in postwar Germany and America, Princeton University Press, Princeton.

Ginibi, R L 1988, Don't Take Your Love to Town, Penguin Australia, Ringwood.

Grieves, V 2008, “The "Battlefields": Identity, authenticity and Aboriginal knowledges in Australia', in H Minde (ed.), Indigenous Peoples: Selfdetermination, knowledge, Eburon, Delft, pp. 287-311.

Haag, O 2013, “'Was sind denn Nicht-Roma, wenn ich Sie fragen darf?": Eine Untersuchung zu Bildern von Oberwart', in $\mathrm{M}$ End et al. (eds), Antiziganistische Zustände 2, Unrast Verlag, Münster, pp. 274-290.

Haag, O 2012, 'Bumping Some Bloody Heads Together: A qualitative study of German-speaking readers of Ruby Langford Ginibi's texts', Journal of the European Association of Studies on Australia, vol. 3, no. 1, pp. 114-125.

Haag, O 2010, 'Tasteless, Romantic, and Full of History: The German reception of Australia and Rabbit-Proof Fence', Studies in Australasian Cinema, vol. 4, no. 2, pp. 115-129. 
Ngapartji Ngapartji, In Turn, In Turn: Ego-histoire, Europe and Indigenous Australia

Haggis, J 2004, 'Thoughts on a Politics of Whiteness in a (Never Quite Post) Colonial Country: Abolitionism, essentialism and incommensurability', in A Moreton-Robinson (ed.), Whitening Race, Aboriginal Studies Press, Canberra, pp. 48-58.

Hancock, I 2008, 'The "Gypsy" Stereotype and the Sexualization of Romani Women', in V Glajar \& D Radulescu (eds), 'Gypsies' in European Literature and Culture, Palgrave Macmillan, New York, pp. 181-191.

Hesse-Biber, S \& P Leavy 2006, The Practice of Qualitative Research, Sage, Thousand Oaks.

Huggins, J 1998, Sister Girl: The writings of Aboriginal activist and historian Jackie Huggins, University of Queensland Press, St Lucia.

Huggins, J \& R 1994, Auntie Rita, Aboriginal Studies Press, Canberra.

Janke, T 1997, Our Culture, Our Future: Proposals for recognition and protection of Indigenous cultural and intellectual property rights, AIATSIS, Canberra.

Lattas, A 1993, 'Essentialism, Memory and Resistance: Aboriginality and the politics of resistance', Oceania, vol. 63, no. 3, pp. 240-267.

Moreton-Robinson, A 2003, 'I Still Call Australia Home: Indigenous belonging and place in a white postcolonizing society', in S Ahmed (ed.), UprootingsRegroundings: Questions of home and migration, Berg, Oxford, pp. 23-40.

Moreton-Robinson, A, M Casey \& F Nicoll 2008, (eds), Transnational Whiteness Matters, Lexington Books, Lanham.

Niethammer, L 2002, Ego-Histoire?: Und andere Erinnerungsversuche, Böhlau, Vienna.

Nora, P 1984, Les lieux dé mémoire, Gallimard, Paris.

Nora, $\mathrm{P}$ et al. 1987, Essais d'Ego-Histoire, Gallimard, Paris.

Painter, N I, 2010, The History of White People, New York, Norton.

Paisley, F 2012, The Lone Protestor: A M Fernando in Australia and Europe, Aboriginal Studies Press, Canberra.

Peters-Little, F, A Curthoys \& J Docker (eds) 2010, Passionate Histories. Myth, Memory and Indigenous Australia, ANU E Press, Canberra.

Popkin, J 1996, 'Ego-Histoire and Beyond: Contemporary French historianautobiographers', French Historical Studies, vol. 19, no. 4, pp. 1139-1167. 
Popkin, J 2007, 'Ego-Histoire Down Under: Australian historianautobiographers', Australian Historical Studies, vol. 38, no. 29, pp. 106-123.

Reynolds, H 1999, Why Weren't We Told?: A personal search for the truth about our history, Penguin, Ringwood.

Riggs, D 2006, Priscilla, (White) Queen of the Desert: Queer rights/race, privilege, Peter Lang, New York.

Rose, R 2007, Roma and Sinti: Human rights for Europe's largest minority, Documentation and Cultural Centre of German Sinti and Roma, Heidelberg.

Schulze, W 1996, Ego-Dokumente: Annäherungen an die Geschichte, Akademischer Verlag, Berlin.

Smith, L T 1999, Decolonizing Methodologies: Research and Indigenous peoples, Sage, Thousand Oaks.

von Glasersfeld, E 1995, Radical Constructivism: A way of knowing and learning, Routledge, London.

Yuval-Davis, N 2011, The Politics of Belonging: Intersectional contestations, Sage, Los Angeles.

Zimmermann, M 1989, Verfolgt, Vertrieben, Vernichtet: Die nationalsozialistische Vernichtungspolitik gegen Sinti und Roma, Klartext-Verlag, Essen. 
This text taken from Ngapartji Ngpartji: In turn in turn:

Ego-histoire, Europe and Indigenous Australia

Edited by Vanessa Castejon, Anna Cole, Oliver Haag and Karen Hughes,

published 2014 by ANU Press, The Australian National University, Canberra, Australia. 